\title{
Child Suicide: A Literature Review
}

Thaisa Mariana Saraiva Coimbra';

Thércia Lucena Grangeiro Maranhão ${ }^{2}$; Raphael Rocha Freire ${ }^{3}$; Miriam Delmondes Batista Ana Cláudia de Oliveira Araújo $^{5}$; Célia Costa Gonçalves ${ }^{6}$

\begin{abstract}
More than one million people are practicing suicide around the world, which makes it a significant public health problem. Thus, suicide practice is one of the three most common causes of death among economically productive age groups (15-44 years), and the second cause of death in groups aged 15 to 19 years. Therefore, the main objective of this study is to conduct a Literature Review on Suicide in Childhood in the last 10 years, taking into account the relevance of such publications. For this, in addition to researching articles on the subject, will be used books that deal with the subject, with the purpose of broadening the discussion. In this way, this work can help in the theoretical understanding of suicide and help in the combat to this frequent practice. In view of the above, what is clear is that the issue of child suicide is surrounded by several psychosocial aspects that require the attention of professionals trained to deal with such situation. From this research it was possible to analyze the magnitude of suicide, and how complex the especially in the case of suicide in children. It was found that talking about suicide is a delicate matter, since this topic is still studied and understood as a taboo that causes fear and anxiety in society.
\end{abstract}

Keywords: Suicide; Child; Public Health; Mental Health

\section{Introdution}

Annually more than one million people worldwide commit suicide, which makes it a significant public health problem. In 1998, suicide constituted $1.8 \%$ of the causes of disability, and it is estimated that, by 2020 , that number will increase to $2.4 \%$ (Bertolot et al., 2009).

\footnotetext{
${ }^{1}$ Psychologist. Graduated from the University Center Dr. Leão Sampaio, Unileão, Ceará, Brazil;

${ }^{2}$ Psychologist. Graduated from the Faculty of Human Sciences of Recife - Esuda, Specialist in Management of Work and Education in Health by the School of Public Health of the State of Ceará. Graduated from the Faculty of Medicine of ABC, Health. Professor of the University Center Dr. Leão Sampaio, Member of the Research Ethics Committee of Unileão. Coordinator of the Cariri Nucleus of Abrh-Ceará, Brazil. thercia@leaosampaio.edu.br;

3 Nursing. Graduated from the University Center Dr. Leão Sampaio, Unileão, Ceará, Brazil. raphaelg2@hotmail.com;

${ }^{4}$ Master's Degree student in Unissulivan Inc. miriamdelmondes@ hotmail.com;

${ }^{5}$ Psychologist. Ethos Domus Institute, Ceará, Brazil.

${ }^{6}$ Psychologist. Evolution Course, Ceará, Brazil.
} 
This process usually begins by ideations involving self-destruction, which can be with or without verbal communication, followed by demonstration of intent and suicide threats until it manifests itself in the attempt or consummated act (Abasse et al. 2009; Bastos, 2009). According Fukumitsu (2014), suicide stems from a breakdown in relations with others, with human nature, including the relationship with yourself.

Suicide is one of the three most common causes of death among economically productive age groups (15-44 years), the second cause of death in groups aged 15 to 19 years (Patton et al., 2009) . According to data extracted from the Map of Violence, developed by the Ministry of Health, there was a $40 \%$ increase in the suicide rate among children and preadolescents aged 10 to 14 between 2002 and 2012. (Brasil, 1990 )

In this sense, it becomes relevant to understand how to conceptualize a child. The Statute of the Child and Adolescent (ECA), in its 2nd article, considers a child, for the purposes of the law, a person up to twelve year age incompleted (Brasil, 1990). Because of the social relations and the specifics of children, there are different conceptions about the meaning of children. Thus, it is clear that the concept of child is a mutable concept throughout history. (Maia, 2012, p.16).

It is clear, then, that there is a social discourse that omits front of child suicide discussion in these terms Pedroso (1986) states that there are several myths about suicide in childhood, among them are the ideas that children below six years do not practice suicide or that cases are extremely rare. A study by Schwartz and Schwartz in 1993 showed that of 505 children hospitalized for attempted suicide, 75 were between 6 and 10 years of age making room for increased concern and attention to the mental health of infants.

Therefore, childhood suicide has become a serious public health problem. Based on the above data, the Ministry of Health of Brazil developed in 2005 the National Suicide Prevention Strategy, through the Mental Health Coordination in response to the request of the World Health Organization. The purpose of the creation of this strategy was to minimize suicide numbers in Brazil, reducing the damage caused by the attempt and giving greater attention to the mental health of the population (Seminotti, 2011).

In order to make this discussion broader, in 2014, a campaign called "Yellow September" was launched, promoted by the CVV (Center for Appreciation to Life) together with the CFM (Federal Council of Medicine) and the ABP (Brazilian Association of 
Psychiatry), with the intention of alerting the population about the reality of suicide in Brazil and in the world, carrying out preventive actions. However, this campaign is intended to promote well-being in people who decide to participate, which would be interesting for children who are considered suicidal to be present at those times to better understand what affects them both internally and externally.

Although the increasing number of occurrences in the past years, related to suicidal practice in childhood, it remains a discussed topic (Kuczynski, 2013). In this sense, besides the academic relevance of the theme, it can also identify a social relevance. Thus, this work may help in the theoretical understanding of suicide and help in combating this common practice.

Some gaps related to child suicide were also identified, such as the most frequent age group and the main factors associated with suicidal practice in childhood. These assumptions have raised the following issues: Is this health problem rare? What is the role of society and psychology in preventing this public health problem?

Therefore, the aim of this study is to conduct a Suicide in Childhood Literature Review, over the last 10 years, or previous that, if it is perceived the relevance of such publications in the development of the subject. The specific objectives were: a) Conduct a search for articles related to the topic in the following databases: Online Library, VHL Virtual Health Library and PubMed - National Center for Biotechnology Information; b) To know the issues of greater scientific discussion about the subject of suicide in childhood; c) To identify psychosocial factors discussed in publications that are related to the infants suffering and suicide practice in childhood.

\section{Suicide Concept}

Child suicide is still a subject not so debated in society remaining a social taboo, and therefore, it is often difficult for the public health authorities to know more about it. Thus, it is noted that working with suicide is a delicate matter, since this theme carries out fears, religious and personal beliefs.

Initially, it is important to mention the concept of suicide. This comes from the Latin sui, "own", and caedere, "to kill". Thus, according to Barbosa, Macedo and Silveira (2011), the concept of suicide reflects the intentional act of killing oneself. In this context, it is 
important to mention that suicide arises from a deliberate practice, initiated and practiced by a person with full knowledge or with expectation of a lethal consequence (Souza; Barbosa; Moreno, 2015).

It is observed that in children and adolescents, suicidal behavior includes some thoughts about intentionally committing self-inflicted injuries or death and practices that cause injury or death (Kuczynski, 2013).

According Boarati (2016) infants do not really understand the end of life as a peremptory act, but as a reversible act. They believe they can die and then come back to life. Therefore, some psychologists argue that children under the age of five do not commit suicide. This idea is defended because they believe that the child has no knowledge of death. The child up to 5 years of age has no concept of definitive death, she does not recognize that death is the interruption of life, not understanding the non-reversibility of death (Abreu, 2010).

In view of this, one can gauge the complexity of the subject, especially with regard to the child, since it is complicated to identify factors that lead the child to take his own life. Many of them may be associated with the family context, such as separation from parents; to the school context, when they are bullied, among other issues. With regard to the Bullying phenomenon, it is worth mentioning that according to Barbosa et al. (2016), this phenomenon is related to suicide, since it causes, in the child who experiences it, the weakening of selfesteem, causing its value judgment on life itself to be perceived as diminished. Thus, the signs of suicide in children are more difficult to perceive, since the devices practiced by them are not seen as attempts at death, but rather as accidents (Seminotti, 2011).

Adolescents and children who attempt to commit suicide almost always experience progressive family instability and discord, which leads them to feel unable to maintain contact and seek support from their parents. Looking more closely, it is noted that children of the less favored class practice more suicides than those of the more affluent class. Another common event in contemporary society are the so-called collective suicides. This practice involves people aged 9 to 18 who maintain relationships on the internet with the intention of putting collective suicide into practice (Abreu, 2010).

According to the Suicidology Specific Literature, there are some ways for the subject to self-injure, and from this, suicidal behavior encompasses three concepts, namely, suicidal ideation (thoughts or ideas about suicide and / or planning of death itself ), the suicide attempt 
(the goal of reaping life itself), and consummate suicide (the death of the individual) (Gonçalves; Freitas; Sequeira, 2011).

Therefore, it can be inferred that in addition to the idea of taking his own life, the concept of suicide is associated with other concepts, which will be discussed in the following topics.

\section{Suicide Idea}

High rates of suicide, suicidal ideation and attempts characterize this issue as a major public health challenge. Suicidal ideation according to Araújo, Vieira and Coutinho (2010) would be as a desire, thought and ideas in order to reap life. Thus, ideation is considered as a precedent to the act of suicide (Turecki, 1999).

In terms of the definition of suicidal ideation, it is necessary to mention that this is characterized as a reference to a suicidal thought or idea, along with attitudes and plans that lead the person to commit suicide. Carlson and Cantwell (1982) explain that as people increase their age, the cases and intensity of suicidal ideation increase, especially after puberty.

Suicidal ideation is also analyzed as a risk factor for suicidal behavior. Studies associate it with the risk of attempts. It is also considered as a characteristic of adolescence, since it is part of the process of developing strategies, since they are ways of dealing with existential difficulties in this period of adolescence (Werlang and Borges, Fensterseifer, 2005).

Some studies indicate that some factors imply suicide behaviors, such as the consumption and / or abuse of alcohol and other psychoactive substances, family and / or parental problems, severe mental disorders, terminal illnesses, childhood abuse, previous attempts and ideation suicide, emotional loss, family history of suicide. These are some of the several factors that can lead an individual to commit suicide (Almeida et al., 2009).

In this case, it is noted that suicidal ideation is a predictor of suicide attempts and thus can be analyzed as the first step for the act to be terminated. In these terms, although it is important to study only suicidal ideation, it is difficult to isolate its concept, since thoughts about suicides are often silenced to friends and relatives (Laufer, 2000). Therefore, it is 
necessary to wake up to the fact that the child is not well when more serious behavior occurs, such as the suicide attempt itself (Gonçalves, Freitas \& Sequeira, 2011).

Thus, it is clear that the ideation foreshadows the act of suicide, and thus, it is important for early detection of these types of thoughts. It is also important to understand the reasons for their appearance and the peculiar characteristics of that period. The intensity and depth of these thoughts, as well as the context in which they arise and the inability to detach themselves from them, are factors that differentiate a person who is healthy from the one who is thinking about reaping life.

\section{Suicide Attempt}

As far as the suicide attempt is concerned, it is understood as a conduct that does not produce the result of death, but the person voluntarily self-injures (Correa, Barrero, 2006a). It is estimated that suicide attempts exceed suicide statistics by at least 10 times. However, in any country there is a nationwide record of suicide attempts. (Botega, 2014).

It is important to analyze a suicide attempt as the main risk factor for committing suicide. It is understood that soon after an attempt, the risk of suicide increases by at least a hundred times compared to present levels in the general population (Owens; Horrocks, House, 2002).

In this sense, it is important to emphasize that it is possible to control some existing problems in the suicide attempt through the assistance offered in the hospitals to guarantee quality of life for these people. It is noted that after the attempted suicide, children become more fragile, often proving that they are incompetent because they have not realized the desire to end their lives. In relation to family members, they are also in a delicate situation after the attempt of their being, since they care about their health, besides being in a state of alert for what may happen (Gutierrez, 2014).

In this perspective, the author Botega (2011) states that the attempt must be analyzed and studied from case to case, to verify the diagnosis of that behavior. For him, attempting suicide is a way to signal an alert.

Thus, Angerami-Camon (2002) points out that the attempt of child suicide should not be seen as a domestic accident, because children may also suffer from problems in life and thus may manifest the will to end their lives. However, children's gestures are often seen as 
child's play. In this way, it is necessary for health professionals to focus on infants, since they also demonstrate existential suffering.

One thing to remember, is that suicide attempt is the main behavior for a future execution of the act, so this behavior should be analyzed carefully. Therefore, assigning special treatment to a person who attempted suicide is one of the tactics aimed at avoiding a future suicide.

In addition to these aspects, the family is considered to have a central role in understanding the psychosocial factors that involve child suicide. In order to understand them more thoroughly, the role of this family in this context will be discussed and how the family that goes through this process can be assisted.

\section{Psychologist Intervention}

The issue of child suicide is involved in a number of psychosocial aspects that require the attention of trained professionals to deal with this situation, both in relation to the individual aspects of the infant in this situation, and to familiar aspects, since the family plays a central role in this process.

In terms of the psychology professional, according to Seminotti (2011), this can act from prevention until after the event finished, if it should happen. In the latter case, the work will return to the family, seeking to alleviate the sufferings caused by the loss, and prevent other suicides from happening.

In this sense, the professional of psychology is required to handle care and attention in the peculiarities that are inserted in this situation. Thus, perceiving the child's behaviors and differentiating the habitual ones from the different ways of behaving, whether to call attention or to deal with feelings that are passing, can help the psychologist to identify potential suicide (Seminotti, 2011).

Thus, the main foundation on which the intervention should be based is the building of bond. According to Estellita-Lins, Oliveira and Coutinho (2006), when this is well established, with the family and with the child, the psychologist's work becomes possible, as well as providing the family with greater security and confidence in the professional. As far as the child is concerned, the child transfers to the psychologist positive feelings, perceiving him as the one who provides attention and care. 
From this perspective, the bond is the first step to a good intervention. From it can build a relationship of genuine and harmonic care, in an affective relationship and promotor of attention. Such facts allow the child to construct value on himself based on the value that is imposed on him by the professional of psychology, helping in the strengthening of his weaknesses so that he can resignify those moments in which he perceives the meaning of his life as almost nonexistent.

In these terms, an intervention that proves effective is related to fostering the will to continue living. The help in the identification of values, through which the child can seek, can help it to construct a perspective of the future that forms meanings and senses directed at the value of life and the construction of the future, based on the experiences of the present (Abreu et al. 2010).

In view of these aspects, it is worth mentioning that suicide is a very complex fact to be analyzed in a generalized way, that is, without taking into account the singularities of each child that is involved in this process. Thus, what is shown here are general and basic interventions that can be directed and on which a focal intervention can be built on the singular subject.

\section{Method}

The present study is a review of the literature, this method, according to Gasque (2012), is a way to carry out a review with a survey of the subject of the researched topic, covering articles with results of research, technical books, points of view of authors. In this way, it is normal to observe several literal quotations in the text read. Thus, it is better to perform paraphrases or summaries of the subjects, that is, it is preferable to produce the indirect citations.

In this sense, we implement the steps: 1) A starting question that will guide all access to the studies, and guide the conclusions; 2) The way in which the sources for the study will be selected; 3) A more detailed and critical analysis of the articles that are selected, from the screening of the material by keywords; 4) Analysis of the information, in accordance with the proposed objectives; 5) Interpretation relating to aspects related to the objectives; 6) Updating of the theme, providing new criticisms or suggestions, as a way of contributing to subsequent studies, updating the theme in question. 
The starting question used in this study was: How the scientific literature discusses child suicide?

For the localization of the articles on child suicide, we initially used the triage for titles and abstracts that contained the key words: suicide, child suicide, child and suicide, childhood suicide. The choice of electronic databases occurred because it is the most used and known in Brazil.

SciELO - Scientific Electronic Library Online - is a virtual database that works in partnership with BIREME - Latin American and Caribbean Center for Health Sciences Information. It keeps high quality Brazilian scientific journals, according to the CNPQ National Council of Scientific and Technological Development. They are two important references that constitute a rich collection, allowing observations and analyzes of the situation of Psychology in relation to the issue of child suicide, as well as a better understanding of the most discussed sub-themes (Oliveira et al, 2015).

The articles for this study were randomly selected, that is, as they appeared in the electronic search, when using the keywords. The articles were initially screened for titles and abstracts.

The exclusion criteria were: a) animal studies; b) studies prior to 2006, if they were not relevant to the research; c) editorials and letters to the editor; d) case reports, case series, case-control cases; e) review studies that do not address the subject studied.

\section{Conclusion}

From this research it was possible to analyze the magnitude of the suicide, and how complex its study, especially in the case of suicide in children. It has been found that talking about suicide is a delicate subject, since this subject is still studied and understood as a taboo that causes fear and anguish in society.

Through this study, it was possible to discern knowledge on this issue and also provide learning to all people who have access to this research. It has been realized that therapeutic interventions are essential in helping individuals' mental health as well as their biopsychosocial needs. In addition, it is also an important tool to disseminate knowledge to family members and to society as a whole. 
It is necessary that health professionals, especially those who treat mental health who know how to observe suicidal behavior in children, so that from this, can apply therapeutic and tactical interventions for the purpose of prevention of the act. So much theoretical and practical knowledge must be put into practice, and the senses and humanities must be sensitized and humanized.

Intensification of life-enhancing campaigns, as well as greater attention to mental, psychological and psychiatric problems, may alleviate the problem of suicide rates. It is also important the participation of the family and the society in the perception of behaviors of the infants, so that from this, the necessary measures are taken.

The suicide attempt is a multi-causal event that affects all the people involved, thus reaffirming the importance of research that contributes to understanding this dynamics, promoting the prevention of suicide and improving the care of patients and their families.

With this perspective, this study and reflexes were essential to identify the need for studies on this topic, to improve new means of interventions with the population and the services involved.

Finally, as a foundation to built research, it is expected to families, society and the state expand its horizons in the fight against suicide, seeking promote understanding of the phenomenon in the country and the development of more effective strategies for the prevention of suicide of infants. It is hoped that the research will serve to promote reflection and the possible change in the way to approach the subject of suicide.

\section{References}

Abdallah T. (1998). The Satisfaction With Life Scale (SWLS): Psychometric properties in an Arabic-speaking sample. International Journal of Adolescence and Youth, 7: 113-9.

Abasse, M. L. F. et al. (2009). Análise epidemiológica da morbimortalidade por suicídio entre adolescentes em Minas Gerais, Brasil. Ciência \& Saúde Coletiva, Rio de Janeiro, v.14, n.2, mar./abr. Available in: http://www.scielo.br/scielo.php?script=sci_arttext\&pid=S141381232009000200010. Access in Sep 21. 2016.

Abreu, S. F. (2010). Suicídio Infantil: O que leva uma criança e adolescente a cometerem suicídio? s.n.t. Web Artigos. Available in http://www.webartigos.com/artigos/suicidioinfantil-o-que-leva-uma-crianca-e-adolescente-a-cometerem-suicidio/50656/. Access in Oct 24. 2016. 
Abreu et. al. (2010). Comportamento suicida: fatores de risco e intervenções preventivas. Rev. Eletr. Enf. 2010;12(1):195-200. Available in: http://www.fen.ufg.br/revista/v12/n1/v12n1a24.htm. Access in Nov 05. 2016.

Almeida, S. A. de; Guedes, P. M. M., Nogueira, J. de A.; França, U. de L.; Silva, A. C. de O. (2009) Investigação de risco para tentativa de suicídio em hospital de João Pessoa- PB. Revista Eletrônica de Enfermagem, 11(2), 383-389.

Angerami-Camon, V. (2002) Criança também se autodestrói. Viver Psicologia. São Paulo: Segmento, ano XI(116) p.14.

Araujo, L. C.; Vieira, K. F. L.; Coutinho, M. P. L. (2010). Ideação suicida na adolescência: um enfoque psicossociológico no contexto do ensino médio. Psico-USF (Impr.), Itatiba , v. 15, n. 1, p. 47-57, Apr. . Available in <http://www.scielo.br/scielo.php?script=sci_arttext\&pid=S1413$82712010000100006 \& \operatorname{lng}=\mathrm{en} \& n r m=\mathrm{iso}>$. Access in Nov 06. 2016.

Ariés, P. (1982) O homem diante da morte. v. 2. Rio de Janeiro: Francisco Alves.

Barbosa, F.O.; Macedo, P. C. M.; Silveira, R. M. C. (2011). Depressão e o suícido. Rev. SBPH, Rio de Janeiro , v. 14, n. 1, p. 233-243, jun. Available in $<$ http://pepsic.bvsalud.org/scielo.php?script=sci_arttext\&pid=S151608582011000100013\&lng=pt\&nrm=iso>. Access in Oct 24. 2016.

Bertolote J. M., Fleischmann, A. (2009). A global perspective on the magnitude of suicide mortality. In: Wasserman, D.; Wasserman, C (eds.). Oxford Textbook of Suicidology and Suicide Prevention: a global perspective. Oxford: Oxford University Press. p.91-98. Available in

https://www.researchgate.net/publication/284686448_A_global_perspective_on_the_magnitu de_of_suicide_mortality.Access in Sep 21.2016.

Barbosa, A. K. L.; Parente, T. D. L.; Bezerra, M. M. M.; Maranhão, T. L. G. (2016). Bullying e sua relação com o suicídio na adolescência. Id on Line Rev. Psic. V.10, N. 31. Set-Out. Available in http://idonline.emnuvens.com.br/id Access in Nov 10. 2016.

Bastos, R. L. (2009) Suicídios, Psicologia e vínculos: Uma leitura psicossocial. Psicologia USP, 20(1),67-92

Boarati. M. A. (2016). O suicídio na infância e adolescência - uma realidade que ainda não se mostra. Psicologia Acessível. Available in https://psicologiaacessivel.net/2016/09/21/osuicidio-na-infancia-e-adolescencia-uma-realidade-que-ainda-nao-se-mostra/. Access in 24 de out. de 2016.

Botega. N.J. (2011). Psiquiatria: Tentativa de Suicídio - Avaliação Clínica e Tratamento. s.n.t. 2011. Available in http://saudeakira.blogspot.com.br/2011/09/psiquiatria-tentativa-desuicidio.html. Access in Oct 30. 2016. 
Botega. N.J. (2014). Comportamento suicida: epidemiologia. Psicol. USP, São Paulo, v. 25, n. 3, p. 231-236, Dec. . Available in $<$ http://www.scielo.br/scielo.php?script=sci_arttext\&pid=S010365642014000300231\&lng=en\&nrm=iso>. Access in Nov 03.2016. http://dx.doi.org/10.1590/0103-6564D20140004.

Bossa, Dra. N. A. (1998) Do nascimento ao inicio da Vida Escolar: o que fazer para os filhos darem certo? Revista Psicopedagogia. Vol. 17, São Paulo, Salesianas.

Bowlby, J. (1989) Uma base segura aplicações clínicas de teoria do apego. Porto Alegre: Artmed.

Brazil. (1990). Lei n. 8.069, de 13 de julho de 1990. Dispõe sobre o Estatuto da Criança e do Adolescente. Brasília. Available in: <http://www.planalto.gov.br/ccivil_03/Leis/L8069.htm>. Access in Sep 21.2016.

Carlson, G. A.; Cantwell, D. P. (1982) Comportamento Suicida e Depressão em Crianças e Adolescentes. American Academy of Child Psychiatry, 21(4), 361-368.

Castro. M. P. O. (2005). Suicídio e Família: Concepção de Psicólogos e Psiquiatras. Brasília, $2005 . \quad$ Available in: http://repositorio.uniceub.br/bitstream/123456789/3055/2/20059868.pdf . Access in Oct 31 . 2016.

Cecconello, A. M.; Antoni, C., Koller, S. H. (2003) Práticas educativas, estilos parentais e abuso físico no contexto familiar. Psicologia em Estudo. Maringá, v.8,n. esp.,p.24-54.

Colnago, N. A. S. (1991) Pares "mães bebês síndrome de Down": Estudo da Estimulação e dos aspectos qualitativos da interação. Dissertação de Mestrado, Programa de Pós Graduação em Educação Especial, Centro de Educação e Ciências Humanas, Universidade Federal de São Carlos, São Carlos.

Correa, H.; Barrero, S. P. (2006) O suicídio ao longo dos tempos, In Correa, H., \& Barrero, S. P (Orgs.). Suicídio uma morte evitável (pp. 3-10). São Paulo, Atheneu.

Costa, J.F. (1998) Sem fraude nem favor: estudos sobre o amor romântico. Rio de Janeiro: Rocco.

Estellita-Lins, C.; Oliveira, V. M.; Coutinho, M. F. C. (2006). Acompanhamento terapêutico: intervenção sobre a depressão e o suicídio. Psyche (Sao Paulo), São Paulo, v. 10, n. 18, p. 151-166, set. Available in $<$ http://pepsic.bvsalud.org/scielo.php?script=sci_arttext\&pid=S1415$11382006000200015 \& \operatorname{lng}=$ pt\&nrm=iso>. Access in Nov 06. 2016.

Fukumitsu, K. O. (2014). O psicoterapeuta diante do comportamento suicida. Psicol. USP, São Paulo, v. 25, n. 3, p. 270-275, Dec. Available in $<$ http://www.scielo.br/scielo.php?script=sci_arttext\&pid=S0103- 
65642014000300270\&lng=en\&nrm=iso>. Access in $\quad$ Sep $21 \quad 2016$. http://dx.doi.org/10.1590/0103-6564D20140001.

Fukumitsu, E. (2013). Suicídio na infância e adolescência. Hospital das Clínicas da Faculdade de Medicina da Universidade de São Paulo. Psicologia USP, São Paulo, 2013. Available in http://www.scielo.br/pdf/pusp/v25n3/0103-6564-pusp-25-03-0246.pdf. Access in Oct 26. 2016.

Gasque, K.C.G.D. (2012). Diferença Entre Referencial Teórico E Revisão De literatura. s.n.t. 2012. Available in http://kelleycristinegasque.blogspot.com.br/2012/02/diferenca-entrereferencial-teorico-e.html. Access in Oct 24. 2016.

Gonçalves, A., Freitas, P., Sequeira, C. (2011) Comportamentos Suicidários em Estudantes do Ensino Superior: Factores de Risco e de Protecção. Millenium, 40, 149-159.

Gutierrez, B. A. O. (2014) Assistência hospitalar na tentativa de suicídio. Psicologia USP, v. 25, n.3 p.262-269, 2014. Available in http://www.scielo.br/pdf/pusp/v25n3/0103-6564-pusp25-03-0262.pdf. Access in Oct 31. 2016.

Kuczynski, E. (2013). Suicídio na infância e adolescência. Psicologia USP. v. 25, n. 3, p.246252. Available in http://www.scielo.br/pdf/pusp/v25n3/0103-6564-pusp-25-03-0246.pdf Access in Oct 24. 2016.

Laufer, M. E. (2000) Depressão e ódio a si mesmo. In Laufer, M. (org.) O adolescente suicida (pp. 35-39). Lisboa: Climepsi Editores.

Maia, J. S. (2012) Concepções De Criança, Infância E Educação Dos Professores De Educação Infantil. Universidade Católica Dom Bosco Campo Grande. Available in http://site.ucdb.br/public/md-dissertacoes/11459-janaina-nogueira-maia.pdf. Access in Sep 21. 2016.

Minuchin, P.; Colapinto, J.; Minuchin, S. (1999) Trabalhando com famílias pobres. Porto Alegre: Artes Médicas.

Owens, D.; Horrocks, J.; House, A. (2002) Repetição fatal e não fatal de auto-agressão. Revisão Sistemática. British Journal of Psychiatry 181, 193-199.

Oliveira G. F. de; Batista, H. M. T.; Rufato, D. O.; Maranhão, T. L. G.; Braga, I. B.; Guedes, J. D. (2015) Psicologia Do Trânsito: Uma Revisão Sistemática. Cad. Cult. Ciênc. Ano IX, v.13 n.2, Mar.

Patton, G. C.; et al. (2009). Global patterns of mortality in young people: a systematic analysis of population health data. Lancet, 374: 881-892. Available in http://www.ncbi.nlm.nih.gov/pubmed/19748397. Access in Sep 21. 2016.

Pedroso, J.D. (1986) Suicídio na Infância. Revista AMIRGS, Porto Alegre, v.30, n.4, p.289293. Oct./dez. 
Seminotti, E. P. (2011). Suicídio Infantil: Reflexões Sobre o Cuidado Médico. Psicologia PT. Available in http://www.psicologia.pt/artigos/textos/A0571.pdf Access in Nov 04. 2016.

Silva. S.F. (2009). Suicídio e seu Impacto no Contexto Familiar. Universidade de Santo Amaro. 2009. available in http://www.unisa.br/graduacao/biologicas/enfer/revista/arquivos/2009-1-16.pdf. Access in Oct 31. 2016.

Sigolo, S. R. R. L. (2004) Favorecendo o desenvolvimento infantil: ênfase nas trocas interativas no contexto familiar. In Mendes, E. G.; Almeida, M. A.; Williams L. C. A. (Orgs.). Temas em Educação Especial: avanços recentes (pp.189-195). São Carlos: Edufscar.

Souza, A. C. G.; Barbosa, G. C.; Moreno, V. (2015). Suicídio na Adolescência: Revisão de Literatura Revista Uningá. Vol.43,pp.95-98. Jan-Mar, 2015 available in http://www.mastereditora.com.br/periodico/20150501_135302.pdf . Access in Oct 24. 2016.

Szymanski, H. (2004) Práticas educacionais familiares: a família como foco de atenção psicoeducacional. Estudos de Psicologia.

Turecki, G. (1999) O suicídio e sua relação com o comportamento impulsivo-agressivo. Revista Brasileira de Psiquiatria, 21(suppl. 2), 18-22.

Werlang, B. S. G., Borges, V. R.; Fensterseifer, L. (2005) Fatores de risco ou proteção para a presença de ideação suicida na adolescência. Revista Interamericana de Psicologia, 39(2), 259-266.

How to cite this article (APA): Coimbra, Thaisa M.S.; Maranhão, Thércia L.G.; Freire, Raphael R.; Batista, Miriam D.; Araújo, Ana C. de O.; Gonçalves, Célia C. (2017). Child Suicide: A Literature Review. Am. In. Mult. J., Oct. 2 (3), 3-16.

Received: 5/6/2017.

Accepted: 9/20/2017. 